Sains Malaysiana 50(4)(2021): 1065-1076

http://doi.org/10.17576/jsm-2021-5004-17

\title{
Protective Effect of Copaifera salikounda Heckel against Paracetamol-Induced Hepatorenal Injury in Rat
}

(Kesan Perlindungan Copaifera salikounda Heckel terhadap Kecederaan Hepatorenal Teraruh-Parasetamol pada Tikus)

\begin{abstract}
Chinyere Aloke*, Nwogo Ajuka Obasi, Chinedum Uche Emelike, Patience Nkemjika Ogbu, Godswill Odumero ufebe, Onyebuchi Federick Orinya, Egwu Chinedu Ogbonnia \& Anthony Chinwendu
\end{abstract}

ONYEKWERE

\section{ABSTRACT}

Drug-induced hepatorenal damage is a significant worldwide clinical challenge. In Nigeria, Copaifera salikounda seed pod ethanol extract (CSSPEE) is used in the treatment of many ailments including liver disorders. This study investigated the protective efficacy of CSSPEE against paracetamol (PCM) induced hepatorenal toxicity. Male albino Wistar rats were assigned at random into five different groups $(n=6)$. The normal control (Group I) was given normal saline via oral administration while Group II was given $500 \mathrm{mg} / \mathrm{kg}$ body weight of PCM via intra-peritoneal administration; Group III was administered $100 \mathrm{mgkg}^{-1}$ of silymarin (reference drug) while Groups IV and V were administered 200 and $400 \mathrm{mg} \mathrm{kg}^{-1}$ of CSSPEE, respectively, per os for seven days prior to administration of PCM. CSSPEE pretreated groups protected $P C M$-induced hepatorenal damage as reflected by significant diminution $(P<0.05)$ in liver enzymes activities and levels of malondialdehyde (MDA), total bilirubin (TB), triglycerides (TG) and urea in comparison with group II. Also, CSSPEE pretreatment significantly increased $(P<0.05)$ the activities of catalase and GSH relative to group II while no significant elevation $(P>0.05)$ in superoxide dismutase (SOD), glutathione peroxidase (GPX), and high-density lipoprotein (HDL) was observed in comparison to PCM group. CSSPEE also reversed liver and kidney PCM overdose caused histopathological alterations and ameliorated the tissue histology thereby corroborating the results of biochemical findings. CSSPEE produced analogous effects comparable to those produced by silymarin (reference drug). The results indicated that oral administration of CSSPEE conferred a dose-dependent protection against paracetamolinduced oxidative damage to liver and kidney.

Keywords: Antioxidant activity; glutathione; hepatoprotective; nephrotoxicity; oxidative stress; paracetamol

\section{ABSTRAK}

Kerosakan hepatorenal yang disebabkan oleh ubat merupakan cabaran klinikal di seluruh dunia. Di Nigeria, ekstrak etanol lenggai Copaifera salikounda (CSSPEE) banyak digunakan dalam rawatan penyakit termasuk gangguan hati. Kajian ini bertujuan mengkaji keberkesanan perlindungan CSSPEE terhadap ketoksikan hepatorenal yang disebabkan oleh parasetamol (PCM). Tikus albino Wistar jantan dibahagikan secara rawak kepada lima kumpulan yang berbeza ( $n$ =6). Kumpulan kawalan normal (Kumpulan I) diberi larutan garam normal melalui oral manakala Kumpulan II adalah kumpulan dengan berat badan $500 \mathrm{mg} / \mathrm{kg}$ PCM melalui intra-peritoneal; Kumpulan III pula diberikan $100 \mathrm{mg} / \mathrm{kg}$ silymarin (ubat rujukan) sementara Kumpulan IV dan V diberikan 200 dan $400 \mathrm{mg} / \mathrm{kg}$ CSSPEE, masing-masing per os selama tujuh hari sebelum diberikan PCM. Kumpulan pra-rawatan CSSPEE yang terlindung daripada kerosakan hepatorenal oleh PCM menunjukkan penurunan yang signifikan $(P<0.05)$ oleh aktiviti enzim hati dan tahap malondialdehid $(M D A)$, total bilirubin (TB), trigliserida (TG) dan urea dibandingkan dengan kumpulan II. Pra-rawatan CSSPEE secara signifikan meningkatkan $(P<0.05)$ aktiviti katalase dan GSH berbanding dengan kumpulan II sementara tidak ada peningkatan yang signifikan ( $P>0.05$ ) pada superoksida dismutase (SOD), glutation peroksidase (GPX) dan lipoprotin berkepadatan tinggi (HDL) dibandingkan dengan kumpulan PCM. CSSPEE juga membalikkan dos terlampau oleh PCM terhadap hati dan ginjal yang menyebabkan perubahan pada histopatologi dan memperbaiki histologi tisu sehingga menunjukkan hasil penemuan biokimia. CSSPEE menghasilkan kesan yang setanding dengan silymarin (ubat rujukan). Hasilnya menunjukkan bahawa pemberian oral CSSPEE memberikan perlindungan bergantung kepada dos terhadap kerosakan oksidatif yang disebabkan oleh parasetamol pada hati dan ginjal.

Kata kunci: Aktiviti antioksidan; glutation; hepatopelindung; nefrotoksisiti; parasetamol; tekanan oksidaan 


\section{INTRODUCTION}

The hepatocyte is the most vital body organ responsible for removal of toxic substances from the body and derangements of this organ remain some of the most serious health problems (Samuel et al. 2012). Hepatic and renal ailments continue to pose significant health challenge and their management is still a difficult problem to orthodox medicine. Acetaminophen commonly called Paracetamol (PCM) is N-acetyl-p-amino-phenol (APAP) frequently used as drug for pain relieve and prevention or reduction of fever (Kanno et al. 2016). Administration of the drug at recommended doses makes it therapeutically safe and effective but when abused and administered at very high dose, it causes severe adverse organ-toxicity effects which principally damages the liver and kidney (Ahmad et al. 2012).

High doses of intentional or accidental ingestion of PCM induce liver and kidney damage (Marotta et al. 2009; Yokozawa \& Dong 2001). At excessive high doses (overdose), the biotransformation and detoxification mechanism of APAP by cytochrome P450 system with sulfate or glucuronide get saturated and results in the synthesis of deleterious metabolic intermediate called $\mathrm{N}$-acetyl-p-benzoquinoneimine (NAPQI). The N-acetylbenzoquinoneimine interacts with sulfhydryl groups in the glutathione (GSH) molecule and oxidize it to form oxidized glutathione (GSSG) thereby exhausting stores of reduced glutathione (GSH) needed for antioxidation in the hepatocyte (Duda-Chodak \& Tarko 2007). The metabolic and pathophysiological link between the kidney and the hepatocyte is inextricable (Orlić et al. 2014). In spite of the fact that renal toxicity mechanism does not directly compare with that of hepatotoxicity, overdose of PCM causes single or multiple organ damage or failure. Robust evidence indicated that patients exposed to PCM overload experience kidney failure (Güvenç et al. 2020). Thus, difficulties resulting from PCM overload via excessive doses have been implicated in hepatotoxicity and renal toxicity and as such the assessment of APAP induced organ damage is absolutely necessary (Güvenç et al. 2020).

Orthodox drugs used in the management of hepatic ailments are insufficient and are associated with serious adverse effects. Thus, there is a worldwide quest for traditional medicinal plants. Many medicinal plants have been reported to be used for the treatment of hepatic diseases (Mitra et al. 2000). Copaifera salikounda which belongs to Caesalpiniaceae family (Leguminosae or Fabaceae) is one of such plants. The seed pod of Copaifera salikounda is remarkable because it is used by rural populace as food ingredient in the preparation of yam porridge, in management of rheumatoid arthritis and is a rich source of flavonoids and phenols (Aloke et al. 2019). Medicinally, the pulped leaves of Copaifera salikounda are employed in the treatment of sore; mixture of its dried leaves and bark with powdered clay treats ulcer while a cold extract of the seed is used in the treatment of vertigo (Oteng-Amoako \& Obeng 2012).

To the best of our knowledge, no report or study has documented experimentally proved evidence on the protective potentials of Copaifera salikounda seed pod ethanol extract (CSSPEE) against liver and kidney damage caused by paracetamol induction. Therefore, this study investigated the protective potentials of CSSPEE on hepatorenal injury induced in rats with paracetamol overdose.

\section{Materials AND Methods}

DRUG AND CHEMICAL

In this study, all the drugs and chemicals (standard grade) used were purchased from Sigma-Aldrich, USA.

\section{COLLECTION AND IDENTIFICATION OF PLANT SAMPLE}

The C. salikounda Heckel seed pods (CSSP) were obtained in November, 2018 from a nearby farm land at Umuigboke village in Ohaozara Local Government of Ebonyi State Nigeria; authenticated by Plant Taxonomist, Mr. Alfred Ozioko of the International Centre for Ethnomedicine and Drug Development Nsukka, Enugu State Nigeria and the voucher specimen (ID: InterCEDD/16281) deposited at the center.

\section{PREPARATION OF PLANT EXTRACTS}

The dried Copaifera salikounda seed pods were further dried under shade and grounded using mortar and pestle to obtain the fine particle and sieved through $<2 \mathrm{~mm}$ mesh to obtain the powdered form. The ethanol extract was prepared by macerating $153 \mathrm{~g}$ of powdered C. salikounda Heckel seed pods (CSSP) in one liter of absolute ethanol for three consecutive days. Thereafter, the extract was filtered through Whatman No. 42, concentrated to about one third of the volume in a water bath maintained at 70 ${ }^{\circ} \mathrm{C}$, dried in vacuo and weighed. The yield was $74 \mathrm{~g}$ which is $48.37 \%$.

\section{EXPERIMENTAL ANIMALS}

In this study, 30 male albino Wistar rats weighing from 160 to $180 \mathrm{~g}$ were used. The albino Wistar rats were housed in the Animal House, Alex Ekwueme Federal University Ndufu-Alike, Nigeria under standard 
environmental conditions $\left(25^{\circ} \mathrm{C}\right.$ and $12 \mathrm{~h}$ dark/12 $\mathrm{h}$ light cycle) and were allowed free access to animal feed (Chikun Feed LTD, Kaduna) and clean water ad libitum. Approval for the experimental protocols was granted by Alex Ekwueme Federal University Ndufu-Alike Nigeria Research and Ethics Committee of Faculty of Basic Medical Sciences with approval ID: FBMS/EC/AE/1867. Prior to commencement of the treatment, the rats were acclimatized for seven days and were humanely treated in line with the provisions of NIH Guidelines for laboratory animals (NRC 1985).

\section{ACUTE TOXICITY TEST}

The study involving acute toxicity of Copaifera salikounda seed pod ethanol extract (CSSPEE) were carried out using the method of Lorke (1983) as outlined with modifications by Aloke et al. (2019). Thus, two doses (200 and $400 \mathrm{mg} / \mathrm{kg}$ ) of CSSPEE adjourned to be safe doses were selected in the study and dissolved in normal saline prior to usage.

\section{EXPERIMENTAL DESIGN}

\section{INDUCTION OF HEPATOTOXICITY AND NEPHROTOXICITY}

Hepatotoxicity and nephrotoxicity were induced according to previously described methods by intraperitoneal injection of $500 \mathrm{mg} / \mathrm{kg}$ of paracetamol (Hasanein \& Sharifi 2017; Kandemir et al. 2017).

\section{EXPERIMENTAL GROUPS}

After acclimatization for seven days, the albino Wistar rats were assigned at random into five different groups $(n=6)$ with different treatment for each group. The normal control group (Group I) were given normal saline via oral administration for seven days, Group II (PCMinduced control) were given $500 \mathrm{mg} / \mathrm{kg}$-body weight of paracetamol (PCM) via intra-peritoneal administration on the seventh day without any pretreatment. Group III (positive/silymarin control) were given $100 \mathrm{mg} /$ kg-body weight of silymarin in normal saline via oral administration for seven days and on the seventh day intoxicated with paracetamol via intra-peritoneal administration of $500 \mathrm{mg} / \mathrm{kg}$-body weight of PCM in normal saline. Groups IV and V were given 200 and 400 $\mathrm{mg} / \mathrm{kg}$-body weight, respectively of Copaifera salikounda seed pod ethanol extract (CSSPEE) in normal saline via oral administration for seven days and on the seventh day intoxicated with paracetamol via intra-peritoneal administration of $500 \mathrm{mg} / \mathrm{kg}$-body weight of PCM in normal saline.
On the fourth day after induction with the paracetamol, the animals were sacrificed and blood collected into plain bottles via cardiac puncture. The blood was then centrifuged at $1000 \mathrm{rmp}$ for $30 \mathrm{~min}$ to separate the serum from the plasma. The serum was stored at $4{ }^{\circ} \mathrm{C}$ prior to analysis. The liver and kidney were also collected in a container containing formalin and stored at room temperature $\left(25^{\circ} \mathrm{C}\right)$ prior to analysis.

\section{BIOCHEMICAL ANALYSES}

The liver function parameters were investigated by assessing the concentration of serum total bilirubin and albumin and alanine aminotransferase (ALT), aspartate aminotransferase (AST) and alkaline phosphatase (ALP) activities spectrophotometrically using commercial test kits from Sigma Aldrich Saint Louis U.S.A in line with the manufacturer's instructional guides. The oxidative stress markers were determined; serum superoxide dismutase (SOD) activities in serum were quantified using McCord and Fridovich (1969) method, serum catalase (CAT) activities were assayed using Sinha (1972) method, serum glutathione peroxidase (GPx) activities were quantified using Rotruck et al. (1973) method while reduced glutathione (GSH) levels were determined using Ellman (1959) method. Serum malondialdehyde (MDA) levels were evaluated spectrophotometrically via quantification of thiobarbituric acid reactive substance (TBARS) using Buege and Aust (1978) method. The levels of serum urea and creatinine (renal function parameters) were determined spectrophotometrically using commercial test kits obtained from Sigma Aldrich Saint Louis U.S.A. according to manufacturer's instructions. Total cholesterol (TC), triglyceride (TG) and high-density lipoprotein-cholesterol (HDL) (lipid profile parameters) were determined colorimetrically in line with the instructional guides in commercial test kits obtained from Sigma Aldrich Saint Louis U.S.A. while low density lipoprotein and very low-density lipoprotein were quantified using Friedewald et al. (1972) formula.

\section{HISTOPATHOLOGY}

The liver and kidney tissue samples harvested were washed using normal saline and transferred immediately to neutral buffered $10 \%(\mathrm{v} / \mathrm{v})$ formalin solution for preservation and storage for at least $48 \mathrm{~h}$. The preserved samples were thereafter subjected to dehydration using graded ethanol. The dehydrated samples were cleared using xylene and then implanted in paraffin. With the aid rotary microtome, $5 \mu \mathrm{m}$ of the processed liver and kidney tissue sections were made and then stained 
using hematoxylin and eosin ( $\mathrm{H}$ and $\mathrm{E})$. The stained sections of the processed tissue samples were mounted for microscopic examination and any changes in their histopathology were noted. The photomicrographs of the histopathological changes observed in the stained samples were taken with MoticTM light microscope camera with 5.0 megapixels resolution quality.

\section{STATISTICAL ANALYSIS}

The results were expressed as mean \pm standard error of mean (SEM). The means of the results were subjected to one-way analysis of variance (ANOVA) and analyzed using statistical packages for social sciences (SPSS) software (IBM, Corp., Atlanta, GA, version 20.0). Differences in the mean of the results were compared using Posthoc Tukey test and significant differences were established at $\mathrm{p}<0.05$.

\section{RESULTS AND DISCUSSION}

\section{EFFECT OF CSSPEE ON LIVER FUNCTION PARAMETERS}

The hepatocyte is greatly affected by noxious agents; consequently, hepatic biomarker enzymes are sensitive indicators of liver toxicity and have been shown to be crucial in the evaluation of hepatic injury. Alanine aminotransferase (ALT), aspartate aminotransferase (AST) and alkaline phosphatase (ALP) activities and serum bilirubin level are widely employed as biomarkers used for liver function test in order to determine its integrity (EI-Faras \& Elsawaf 2017). The liver structural integrity is a reflection of the alteration of these serum markers. Reports have shown that elevation in the activities of aspartate aminotransferase is strongly associated with elevation in the activities of alanine aminotransferase; these aminotransferases play an important role during the reversible conversion of amino acids into keto acids (Sallie et al. 1991). In this study, PCM-induced hepatorenal toxicity in the albino Wistar rats produced significant increase $(p<0.05)$ in the activities of serum alanine aminotransferase, aspartate aminotransferase and alkaline phosphatase and in the level of serum total bilirubin with significant reduction $(p<0.05)$ in the level of albumin when compared to those of the normal control (Table 1). The increase in the activities of the liver enzymes may be ascribed to compromise in structural architectural integrity of the liver. This is because these liver cytoplasmic enzyme biomarkers leak out of injured liver cell cytoplasm and enter into circulation, indicating hepatotoxic injury (Maheswari \& Maryammal 2008). Elevated serum concentration of ALP on administration of PCM overdose may be due to increased production of ALP as a result of pathological changes in biliary flow that caused biliary pressure increase (Plaa \& Hewitt 1989; Sallie et al. 1991). This study showed that CSSPEE pretreatment attenuated the increases in the activities of serum alanine aminotransferase, aspartate aminotransferase and alkaline phosphatase (ALP) and serum bilirubin level produced by paracetamol overdose, demonstrating that it protects hepatic damage produced by PCM overdose (Table 1). This is in consonance with reported evidence that the levels of these liver biomarkers are reduced to normal when hepatic parenchyma cells are healed and hepatocytes regenerated (Saleem et al. 2008). Compelling evidences have shown that flavonoids are able to decrease the serum activity of liver biomarkers in hepatic damaged animal model and as such confer protection on hepatic necrosis to such animal model (Gupta et al. 2015; Krithika \& Verma 2019). Literature report showed that CSSPEE contain high level of flavonoids and phenolic compounds (Aloke et al. 2019) and so, the ability of this extract to inhibit APAP-induced liver damage may be accredited to be due to the presence of these compounds.

Bilirubin is a toxic, insoluble breakdown product of hemoglobin which undergoes biotransformation reaction in the liver to produce a detoxified conjugated glucuronide that is water-soluble and could easily be excreted. Changes in serum bilirubin are therefore a biomarker of cellular liver dysfunction. Thus, hepatic function can be assessed using serum bilirubin and any unusual elevation is indicative of hepatobiliary ailments that may cause profound cellular dysfunction of liver (Martin \& Friedman 1992). The diminution in concentration of bilirubin following CSSPEE pretreatment in this study (Table 1) is an indication that the extract is efficacious in the treatment of hepatic injury in paracetamol-induced oxidative damage. This restorative effect of CSSPEE may be attributed to the presence of their constituent flavonoids with its proven antioxidant potentials. The observed reduction in albumin concentration in PCM-treated albino Wistar rats (group 2) may be linked to the reduction in the number of liver cells that consequently culminated in decreased capacity of the liver to synthesize albumin (Okokon et al. 2017). This reduction in albumin synthesis was ameliorated by CSSPEE pretreatment and thus, showed that CSSPEE improve the functional integrity of hepatocytes. 
TABLE 1. Results of the effects of CSSPEE on liver cellular biomarkers of paracetamol-induced hepatorenal damage in rats

\begin{tabular}{cccccc}
\hline Parameters & Group I & Group II & Group III & Group IV & Group V \\
\hline AST (U/L) & $21.2 \pm 1.07$ & $51.2 \pm 0.86^{*}$ & $28.0 \pm 0.55^{\#}$ & $29.4 \pm 1.60^{\#}$ & $33.0 \pm 1.34^{\#}$ \\
ALT (U/L) & $17.4 \pm 0.65$ & $25.6 \pm 0.51^{*}$ & $19.4 \pm 1.08^{\#}$ & $17.6 \pm 0.81^{\#}$ & $24.2 \pm 0.80^{\#}$ \\
ALP (U/L) & $21.6 \pm 0.98$ & $30.6 \pm 1.17^{*}$ & $23.2 \pm 0.86^{\#}$ & $20.0 \pm 2.39^{\#}$ & $24.8 \pm 0.97^{\#}$ \\
TB (mg/dL) & $0.48 \pm 0.72$ & $0.64 \pm 0.04^{*}$ & $0.48 \pm 0.24^{\#}$ & $0.53 \pm 0.02^{\#}$ & $0.47 \pm 0.28^{\#}$ \\
Albumin (g/dL) & $2.64 \pm 0.12$ & $2.12 \pm 0.04^{*}$ & $2.40 \pm 0.09$ & $2.42 \pm 0.05^{\#}$ & $2.94 \pm 0.15^{\#}$ \\
\hline
\end{tabular}

Values are mean $\pm \mathrm{SEM}, \mathrm{n}=5, \mathrm{AST}=$ aspartate aminotransferase, $\mathrm{ALT}=$ alanine aminotransferase, $\mathrm{ALP}=$ alkaline phosphatase, $\mathrm{TB}=$ total bilirubin, $\mathrm{CSSPEE}=$ Copaifera salikounda seed pod ethanol extract. "= significant difference $(\mathrm{p}<0.05)$ between Group II and Group I (normal control); ${ }^{\#}=$ significant difference $(\mathrm{p}<0.05)$ in Groups III, IV and V compared with Group II (negative control); Group 1= normal control, Group 2= negative control (paracetamol only), Group $3=$ positive control (silymarin 100 $\mathrm{mg} / \mathrm{kg}+$ paracetamol $500 \mathrm{mg} / \mathrm{kg}$ ), Group $4=$ CSSPEE $200 \mathrm{mg} / \mathrm{kg}+$ paracetamol $500 \mathrm{mg} / \mathrm{kg}$, Group 5= CSSPEE $400 \mathrm{mg} / \mathrm{kg}+$ paracetamol $500 \mathrm{mg} / \mathrm{kg}$

\section{EFFECTS OF CSSPEE ON OXIDATIVE STRESS BIOMARKERS}

Oxidative stress is a vital mechanism that has been proposed to be crucial in the development of paracetamol toxicity (El-Morsy \& Kamel 2015). The endogenous defense system by enzymatic and non-enzymatic antioxidants is the natural mechanism by which living system shield itself against lipid peroxidation. Superoxide dismutase, catalase and glutathione peroxidase are crucial enzymes which mop up reactive oxygen species such as hydrogen peroxide and superoxide ion. These anti-oxidative enzymes guard against the hydroxyl radical formation and shield the constituents of the cells against injury by these reactive oxygen and nitrogen species (Scott et al. 1991). Liver toxicity associated with acetaminophen administration has been proposed to be occasioned by peroxidation of lipids (Dash et al. 2007). The results of the effects of CSSPEE on oxidative stress biomarkers are shown in Figure 1(A)-1(E). The results showed that overdose of PCM $(500 \mathrm{mg} / \mathrm{kg}$-bw) administered to the albino Wistar rats caused a significant decrease $(\mathrm{p}<0.05)$ in CAT activities and the level of GSH but non-significant decrease $(p>0.05)$ in the SOD activities when compared with those of Group 1 (negative control). In addition, the results of GPx were unexpected as we observed no marked effect of our drug and treatment in this study. From these results (Figure 1), reduced glutathione depletion in PCM-intoxicated groups may be attributed to formation of mercapturic acid in a reaction involving conjugation of N-acetyl-p-benzoquinoneimine (NAPQI) with reduced GSH. Glutathione, a non-enzymic antioxidant, is a tripeptide which is mostly abundant in the hepatocyte. It functions primarily as a scavenger in the removal of free radical species such as alkoxy radicals, hydrogen peroxide and superoxide radicals. Glutathione is a major substrate of glutathione peroxidase and transferase which is involved in the maintenance of the integrity of membrane protein thiols (Prakash et al. 2001). Increase in the level of GSH measured in this study is indicative of the presence of antioxidant in the CSSPEE. The results (Figure 1) also showed that PCM overdose (Group 2) caused significant increase $(p<0.05)$ in the level of MDA when compared to those in Group 1 (normal control). The elevation in the level of malondialdehyde (MDA) is indicative of increased lipid peroxidation as a result of compromised anti-oxidative defense mechanism, leading to tissue damage. Interestingly, the study showed that CSSPEE pretreatment prior to PCM intoxication considerably attenuated the alterations in oxidative stress biomarkers (Figure 1(B)). Robust evidence has shown that SOD is one of the crucial enzymes in the enzymatic antioxidant defense system (Yao et al. 2015). Catalase is seen in all animal tissue but its activity is predominantly higher in the red cells and liver (Aseervatham et al. 2014). SOD guards against highly reactive superoxide radical and transform them to hydrogen peroxide $\left(\mathrm{H}_{2} \mathrm{O}_{2}\right)$ and water while $\mathrm{H}_{2} \mathrm{O}_{2}$ is further degraded to water by CAT and GPx (Mahesh et al. 2014). The diminution of activities of SOD and CAT 
in this study indicated a decrease in the antioxidative capacity as well. The decreased activities of SOD and CAT on PCM intoxication may be ascribed to their consumption in the detoxification of ROS and also due to increasing peroxidation of lipid (Halliwell \& Gutteridge 1984). Hydrogen peroxide inhibits SOD while the activities of CAT and GPx are inhibited by excess of superoxide radical (Pigeolet et al. 1990). Our earlier phytochemical screening of CSSPEE has shown that it is rich in phenols, flavonoids, saponins, and tannins (Aloke et al. 2019). It has been reported in literature that flavonoid exert antioxidant (Ferreira et al. 2010; Tapas et al. 2008), anti-inflammatory (Sandhar et al. 2011) and hepatoprotective (Sandhar et al. 2011; Tapas et al. 2008) effects. Besides, saponins have been shown to elicit hepatoprotective effect through modulation of its antioxidant (Elekofehinti et al. 2012) and anti-inflammatory potentials (Akkol et al. 2007) while tannins have been shown to have free radical scavenging and antioxidant, anti-inflammatory, and hepatoprotective effects (Pithayanukul et al. 2009). The syngistics effects of the phytoconstituents of CSSPEE might have accounted for the significant increase in activities of CAT and SOD in CSSPEE pretreated rats in comparison to PCM intoxicated control. The insignificant alterations in the activity of GPx and non-significant decrease in the activity of SOD in PCM control group (Group 2) may probably be related to the severity of liver injury as well as the extent of lipid peroxidation due to the duration of the study.

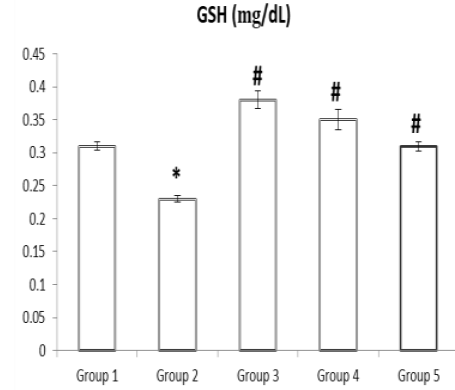

A

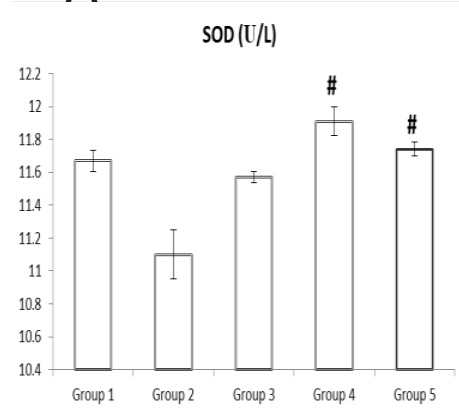

C

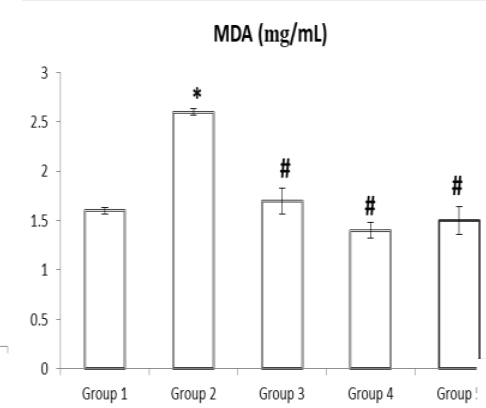

B

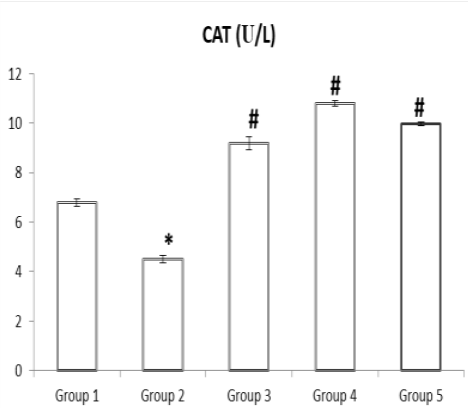

D
GPx (U/L)

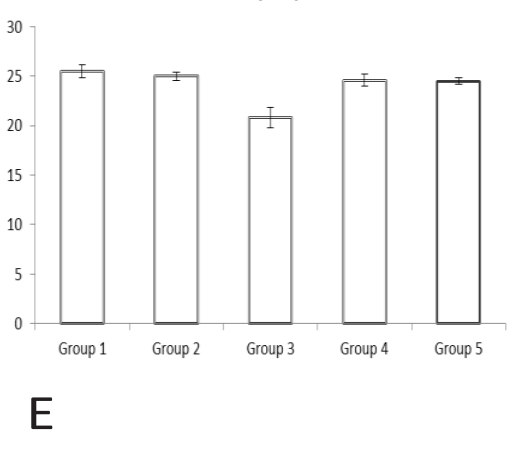

FIGURE 1(A-E). Results of the effects of CSSPEE on oxidative stress biomarkers of paracetamol-induced hepatorenal damage in albino Wistar rats. Legend. Values are mean $\pm \mathrm{SEM}, \mathrm{n}=5, \mathrm{~A}$ : GSH $=$ reduced glutathione, $\mathrm{B}: \mathrm{MDA}=$ malondialdehyde, $\mathrm{C}: \mathrm{SOD}=$ superoxide dismutase, $\mathrm{D}: \mathrm{CAT}=$ catalase, $\mathrm{E}: \mathrm{GPx}=$ glutathione peroxidase. $\mathrm{CSSPEE}=$ Copaifera salikounda seed pod ethanol extract. $\mathrm{PCM}=$ paracetamol. $^{*}=$ significant difference $(\mathrm{p}<0.05)$ between Group II and Group I (normal control); ${ }^{*}=$ significant difference $(\mathrm{p}<0.05)$ in Groups III, IV and V compared with Group II (negative control); Group 1 = normal control, Group 2 = negative control, Group 3 = positive control (silymarin $100 \mathrm{mg} / \mathrm{kg}+$ PCM $500 \mathrm{mg} / \mathrm{kg}$ ), Group 4

$=\mathrm{CSSPEE} 200 \mathrm{mg} / \mathrm{kg}+\mathrm{PCM} 500 \mathrm{mg} / \mathrm{kg}$, Group 5 = CSSPEE $400 \mathrm{mg} / \mathrm{kg}+\mathrm{PCM} 500 \mathrm{mg} / \mathrm{kg}$ 


\section{EFFECT OF CSSPEE ON KIDNEY FUNCTION PARAMETERS}

Urea and creatinine are biomarkers which derangements are mostly linked with paracetamol overdose. An elevation in the serum urea and creatinine concentration has been reported as a dependable index for evaluating drug-induced kidney toxicity in animals (Mandal et al. 2015). Renal ailment and functional derangement could perhaps result when the level of serum urea accumulates in excess of its clearance rate. Similarly, elevations in serum creatinine levels have been reported as renal function derangement (Yousef et al. 2010). PCM overdose brings about alterations in metabolism including elevations in serum urea and creatinine (Srinivasan et al. 2014). In renal disorders, increased plasma urea occurs due to accelerated rate of plasma urea synthesis which exceeds the rate of urea clearance (Mayne 1994). The results of the effects of CSSPEE and PCM on the levels of serum urea and creatinine are shown in Table 2 . The results showed that injection of PCM to albino Wistar rats significantly ( $p<$ $0.05)$ increased the levels of serum urea and creatinine in group 2 (PCM control) relative to those of the normal rats ( $p$ $<0.05)$. The increased urea concentration in PCM-induced hepatotoxic albino Wistar rats is probably due to increased breakdown of amino acid, compromise in kidney function, or hepatic derangement (Pedraza-Chaverrí et al. 2004; Yang et al. 2012). Catabolism of tissue creatinine culminates in elevated plasma creatinine level when there is kidney damage. The results further shown that groups pretreated with 200 and $400 \mathrm{mg} / \mathrm{kg}$ of CSSPEE showed dose dependent significant reduction $(\mathrm{p}<0.05)$ in the level of serum urea when comparison to PCM control in dose dependent manner. Similarly, significant reduction $(p<0.05)$ in the level of creatinine was observed in the silymarin pretreated group when compared with group 2 while there was non-significant difference $(p>0.05)$ in the levels of serum creatinine in CSSPEE pretreated groups compared with PCM intoxicated group (Group 2). The non-significance decrease in creatinine level in pretreated groups may be related to the duration of the study. This study showed that CSSPEE pretreatment significantly decreased serum urea levels elevated by PCM overdose and as such protected the renal cells (Table 2). Therefore, CSSPEE pre-treatment mitigated renal injury by protecting them against PCM-induced renal damage leading to the elevation of serum urea and creatinine.

TABLE 2. Results of the effects of CSSPEE on the kidney function parameters of paracetamol-induced hepatorenal damage in rats

\begin{tabular}{cccccc}
\hline $\begin{array}{c}\text { Groups } \\
\text { parameters }\end{array}$ & Group I & Group II & Group III & Group IV & Group V \\
\hline Urea $(\mathrm{mg} / \mathrm{dL})$ & $22.6 \pm 1.81$ & $67.8 \pm 1.69^{*}$ & $61.4 \pm 1.29$ & $58.4 \pm 1.78^{\#}$ & $56.8 \pm 2.40^{\#}$ \\
Creatinine $(\mathrm{mg} / \mathrm{dL})$ & $0.36 \pm 0.017$ & $1.06 \pm 0.076^{*}$ & $0.54 \pm 0.035^{\#}$ & $1.00 \pm 0.041$ & $0.95 \pm 0.046$ \\
\hline
\end{tabular}

Legend. Values are mean \pm SEM, $n=5$, CSSPEE $=$ Copaifera salikounda seed pod ethanol extract. "= significant difference ( $p<0.05)$ between Group II and Group I (normal control); ${ }^{*}=$ significant difference $(\mathrm{p}<0.05)$ in Groups III, IV and V compared with Group II (negative control); Group 1= normal control, Group 2= negative control (paracetamol only), Group 3= positive control (silymarin $100 \mathrm{mg} / \mathrm{kg}+$ paracetamol $500 \mathrm{mg} / \mathrm{kg}$ ), Group $4=$ CSSPEE $200 \mathrm{mg} / \mathrm{kg}+$ paracetamol $500 \mathrm{mg} / \mathrm{kg}$, Group $5=\mathrm{CSSPEE} 400 \mathrm{mg} / \mathrm{kg}+$ paracetamol $500 \mathrm{mg} / \mathrm{kg}$

\section{EFFECT OF CSSPEE ON LIPID PROFILE}

In this study, the results in Table 3 showed a dose dependent significant decrease $(\mathrm{p}<0.05)$ in the level of very low density lipoprotein-cholesterol (VLDL-C), triglyceride (TG) and total cholesterol (TC), insignificant ( $\mathrm{p}>0.05)$ decrease in low density lipoprotein-cholesterol (LDL-C), but a non-significant increase $(\mathrm{p}<0.05)$ in the level of high density lipoprotein-cholesterol (HDL-C) and in CSSPEE pretreated groups compared to those of PCM-induced hepatorenal toxic albino Wistar rats group (Group 2). Lipid peroxidation is usually orchestrated by oxidative stress conditions and this is reflected by elevated serum malondialdehyde levels. Acetaminophen, the active compound in paracetamol has been demonstrated as an agent that depletes glutathione pool in the cells thereby interfering with the antioxidants defense system of an organism (Egbung et al. 2017). The results of this study showed that administration of CSSPEE mimics the mechanism that replenishes lost reduced glutathione and as such prevent the synthesis of free radicals caused by paracetamol overdose. Substantive proofs exist with regards to the notion that HDL cholesterol is inversely linked with total body cholesterol; a diminution of plasma HDL cholesterol concentration may increase the 
development of atherosclerosis, resulting to ischemic heart disease, by impairing the removal of cholesterol from the arterial wall (Kanungo et al. 2007). Previous studies have reported that flavonoids and phenolic compounds hinder oxidation processes and are cytotoxic, culminating in formation of various ailments (Duda-Chodak \& Tarko 2007). These flavonoids and phenolic compounds have been demonstrated to elevate the concentration of high-density lipoprotein cholesterol and reduce the levels of low-density lipoprotein cholesterol (LDL-C) and very low-density lipoprotein cholesterol (VLDL-C) in hypercholesteremic and hepatotoxic albino Wistar rats (Patel et al. 2009). Flavonoids, phenols, and other antioxidant components of CSSPEE (Aloke et al. 2019) may be implicated as being responsible for increasing HDL and decreasing total cholesterol (TC), triglyceride (TG), low density lipoprotein cholesterol (LDL-C), and very low-density lipoprotein cholesterol (V(LDL) in CSSPEE pretreated groups. The decrease in LDL by the extract may be as a result of changes in the small intestine that perhaps increase liver LDL-receptor and diminution in transforming of VLDL to LDL (Vidal-Quintanar et al. 1997). In this present study, the observation that the extract had insignificant effect on the HDL-cholesterol is comparable with other studies (Olatunji et al. 2005; Ulrich 1987) showed that consumption of some dietary plants lower plasma LDL-C without interfering with HDL-C levels. The elevation in TC in acetaminophen induced toxicity might be due to biliary obstruction (Zhao \& $\mathrm{Hu}$ 2013) while hypertriglyceridemia may be as a result of interference or inhibition of triglycerides secreting mechanism (Kosanic \& Rankovic 2011). However, pretreatment with the extract attenuated these elevations in TC and TG.

TABLE 3. Results of the effects of CSSPEE on lipid profile of paracetamol-induced hepatorenal damage in rats

\begin{tabular}{cccccc}
\hline $\begin{array}{c}\text { Groups } \\
\text { parameters }\end{array}$ & Group I & Group II & Group III & Group IV & Group V \\
\hline TC $(\mathrm{mg} / \mathrm{dL})$ & $4.04 \pm 0.160$ & $4.46 \pm 0.093$ & $3.96 \pm 0.157$ & $3.74 \pm 0.166^{\#}$ & $3.82 \pm 0.198$ \\
$\mathrm{HDL}(\mathrm{mg} / \mathrm{mL})$ & $1.67 \pm 0.077$ & $1.16 \pm 0.070^{*}$ & $1.23 \pm 0.044$ & $1.32 \pm 0.031$ & $1.22 \pm 0.026$ \\
$\mathrm{LDL}(\mathrm{mg} / \mathrm{mL})$ & $1.79 \pm 0.142$ & $2.11 \pm 0.110$ & $2.01 \pm 0.128$ & $1.81 \pm 0.127$ & $1.92 \pm 0.153$ \\
VLDL $(\mathrm{U} / \mathrm{L})$ & $0.23 \pm 0.019$ & $0.34 \pm 0.010^{*}$ & $0.26 \pm 0.025$ & $0.24 \pm 0.014^{\#}$ & $0.28 \pm 0.015$ \\
$\mathrm{TG}(\mathrm{U} / \mathrm{mg})$ & $1.10 \pm 0.078$ & $1.70 \pm 0.055^{*}$ & $1.40 \pm 0.063$ & $1.36 \pm 0.060^{\#}$ & $1.42 \pm 0.49^{\#}$ \\
\hline
\end{tabular}

Values are mean $\pm \mathrm{SEM}, \mathrm{n}=5, \mathrm{TC}=$ total cholesterol, $\mathrm{HDL}=$ High density lipoprotein, $\mathrm{LDL}=$ low density lipoprotein, $\mathrm{VLDL}=$ very low-density lipoprotein, $\mathrm{TG}=$ triglyceride, CSSPEE = Copaifera salikounda seed pod ethanol extract. ${ }^{*}=$ significant difference $(\mathrm{p}<0.05)$ between Group II and Group I (normal control); ${ }^{*}=$ significant difference $(\mathrm{p}$ $<0.05$ ) in Groups III, IV and V compared with Group II (negative control); Group 1 = normal control, Group 2 = negative control (paracetamol only), Group 3 = positive control (silymarin $100 \mathrm{mg} / \mathrm{kg}+$ paracetamol $500 \mathrm{mg} / \mathrm{kg}$ ), Group $4=$ CSSPEE $200 \mathrm{mg} / \mathrm{kg}+$ paracetamol $500 \mathrm{mg} / \mathrm{kg}$, Group $5=$ CSSPEE $400 \mathrm{mg} / \mathrm{kg}+$ paracetamol $500 \mathrm{mg} / \mathrm{kg}$

\section{HISTOPATHOLOGY OF THE LIVER AND KIDNEY}

In this study, the results of the histopathology of the liver and kidney are consistent with biochemical findings. Histopathological studies of albino Wistar rats administered paracetamol investigated in this study showed severe degeneration of hepatic tissue with severe portal aggregate of inflammatory cells (SPAIC) (portal hepatitis), severe fatty changes (SFC) and dilated sinusoid (DS) in the liver (Figure 2(A)-2(E)) and severe degeneration of renal tissue with necrosed glomeruli (NG), tubular atrophy (TA), fatty changes
(FC) and intra renal inflammation (IRI) (Figure 3(A)$3(\mathrm{E})$ ). These histological features may be caused by the formation of N-acetyl-p-benzoquinoneimine (NAPQI) due to paracetamol overdose. The results showed that all the histopathological alterations observed were attenuated in CSSPEE pretreated albino Wistar rats. Thus, the histological findings of this study corroborate the biochemical results. These histopathology results confirm the protective role of Copaifera salikounda seed pod ethanol extract which has been demonstrated to cause hepatic and renal cells regeneration and decreased necrosis. 


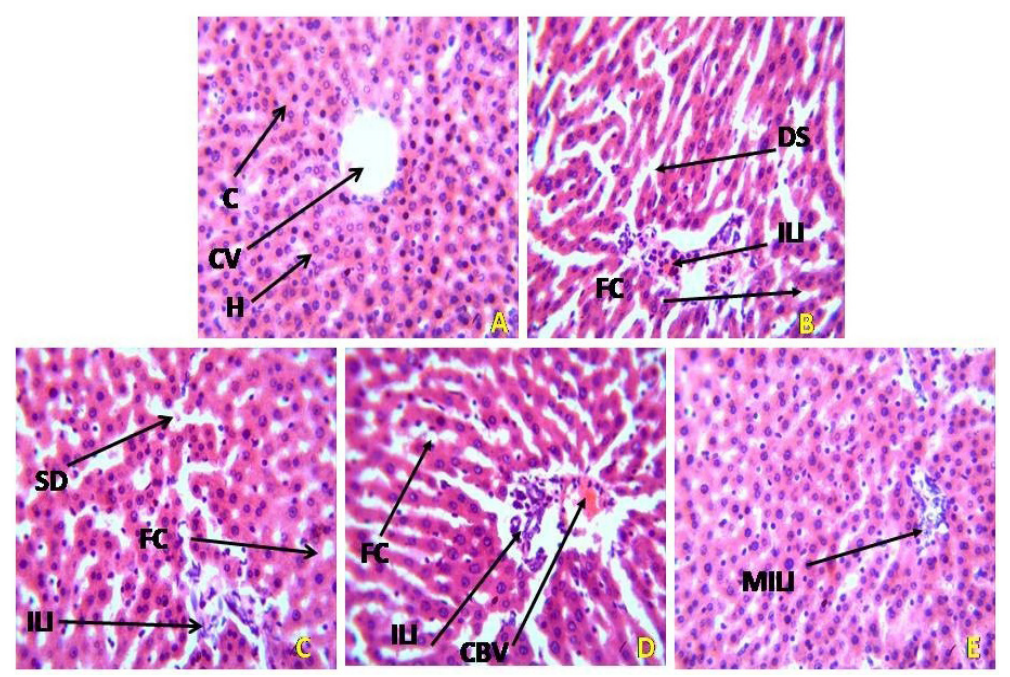

$\mathrm{A}=$ group 1(normal control, $\mathrm{B}=$ group 2(negative control/paracetamol only), $\mathrm{C}=$ positive control (silymarin $100 \mathrm{mg} / \mathrm{kg}$ + paracetamol $500 \mathrm{mg} / \mathrm{kg}$ ), D = group 4 (CSSPEE $200 \mathrm{mg} / \mathrm{kg}$ + paracetamol 500 $\mathrm{mg} / \mathrm{kg}), \mathrm{E}=$ group $5(\mathrm{CSSPEE} 400 \mathrm{mg} / \mathrm{kg}+$ paracetamol $500 \mathrm{mg} / \mathrm{kg})$, central vain $=\mathrm{CV}$, hepatocyte $=\mathrm{H}$, cytoplasm $=\mathrm{C}$, intra lobular inflammation $=\mathrm{ILI}$, fatty changes $=\mathrm{FC}$, dilated sinusoid $=\mathrm{DS} / \mathrm{SD}$, Moderate intra lobular inflammation $=$ MILI, moderate fatty change $=$ MFC , congestion of the blood vessel $=\mathrm{CBV}$

FIGURE 2(A-E). Histopathology of the liver

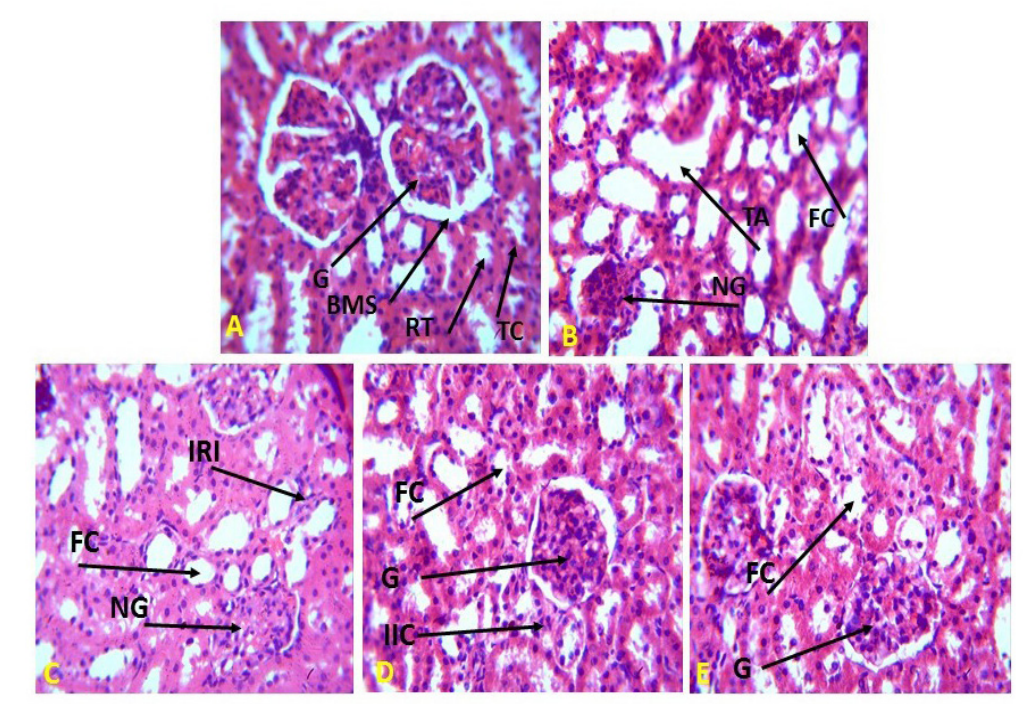

$\mathrm{A}=$ group 1(normal control, $\mathrm{B}=$ group 2(negative control/paracetamol only), $\mathrm{C}=$ positive control (silymarin $100 \mathrm{mg} / \mathrm{kg}+$ paracetamol $500 \mathrm{mg} / \mathrm{kg}$ ), D= group $4($ CSSPEE $200 \mathrm{mg} / \mathrm{kg}+$ paracetamol $500 \mathrm{mg} / \mathrm{kg}), \mathrm{E}=$ group $5(\mathrm{CSSPEE} 400 \mathrm{mg} / \mathrm{kg}+$ paracetamol $500 \mathrm{mg} / \mathrm{kg})$, Glomeruli $=\mathrm{G}$, renal tubules $=\mathrm{RT}$, tubular cell $=\mathrm{TC}$, necrosed glomeruli $=\mathrm{NG}$, tubular atrophy $=\mathrm{TA}$, fatty changes $=\mathrm{FC}$, intra renal inflammation $=$ IRI, infiltration inflammatory cell $=$ IIC

FIGURE 3(A-E). Histopathology of the kidney 


\section{CONCLUSION}

This study showed that Copaifera salikounda seed pod ethanol extract (CSSPEE) contain bioactive compounds that exhibit protective effects in renal cells and hepatocytes via anti-oxidative mechanisms. The protective effects of CSSPEE on renal cells and hepatocytes were demonstrated by the degree of attenuation observed in paracetamol (PCM)-induced damaged in liver and kidney tissues. The medicinal potentials of CSSPEE may be attributed to the presence of flavonoids and/or phenolic compounds as its constituents, which are known to exhibit hepatoprotective and antioxidant potentials. This study showed that CSSPEE has some potential use in the pharmaceutical industries. Further study is required to fractionate the extracts and isolate the bioactive components to clearly elucidate the actual mechanism responsible for its renal and hepatoprotective activity.

\section{ACKNOWLEDGEMENTS}

We are grateful to Prof. C.E.C.C. Ejike and Dr. A.C. Famurewa for their invaluable comments and contributions.

\section{REFERENCES}

Ahmad, S.T., Arjumand, W., Nafees, S., Seth, A., Ali, N., Rashid, S. \& Sultana, S. 2012. Hesperidin alleviates acetaminophen induced toxicity in Wistar rats by abrogation of oxidative stress, apoptosis and inflammation. Toxicol. Lett. 208(2): 149-161.

Akkol, E.K., Tatli, I.I. \& Akdemir, Z.S. 2007. Antinociceptive and anti-inflammatory effects of saponin and iridoid glycosides from Verbascum pterocalycinum var. mutense Hub.-Mor. Z. Naturforsch. C: J. Biosci. 62(11-12): 813-820.

Aloke, C., Ibiam, U.A., Obasi, N.A., Orji, O.U., Ezeani, N.N., Aja, P.M., Alum, E.U. \& Mordi, J.C. 2019. Effect of ethanol and aqueous extracts of seed pod of Copaifera salikounda (Heckel) on complete Freund's adjuvant-induced rheumatoid arthritis in rats. J. Food Biochem. 43(7): e12912.

Aseervatham, G.S.B., Sivasudha, T., Sasikumar, J.M., Christabel, P.H., Jeyadevi, R. \& Ananth, D.A. 2014. Antioxidant and hepatoprotective potential of Pouteria campechiana on acetaminophen-induced hepatic toxicity in rats. J. Physiol. Biochem. 70(1): 1-14.

Buege, J.A. \& Aust, S.D. 1978. Microsomal lipid peroxidation. In Methods in Enzymology. Vol. 52, edited by Flesicher, S. \& Packer, L. New York: Academic Press. pp. 302-310.

Dash, D.K., Yeligar, V.C., Nayak, S.S., Ghosh, T., Rajalingam, D., Sengupta, P., Maiti B.C. \& Maity, T.K. 2007. Evaluation of hepatoprotective and antioxidant activity of Ichnocarpus frutescens (Linn.) R.Br. on paracetamolinduced hepatotoxicity in rats. Trop. J. Pharm. Res. 6(3): 755-765.
Duda-Chodak, A. \& Tarko, T. 2007. Antioxidant properties of different fruit seeds and peels. Acta Sci. Pol. 6(3): 29-36.

Egbung, G.E., Atangwho, I.T., Odey, O.D. \& Ndiodimma, V.N. 2017. The lipid lowering and cardio protective effects of Vernonia calvoana ethanol extract in acetaminophen-treated rats. Medicines 4(4): 90

EI-Faras, A.A. \& Elsawaf, A.L. 2017. Hepatoprotective activity of quercetin against paracetamol-induced liver toxicity in rats. Tanta Med. J. 45(2): 92-98.

Elekofehinti, O.O., Adanlawo, I.G., Komolafe, K. \& Ejelonu, O.C. 2012. Saponins from Solanum anguivi fruits exhibit antioxidant potential in Wistar rats. Ann. Biol. Res. 3(7): 3212-3217.

Ellman, G.L. 1959. Tissue sulfahydryl groups. Arch. Biochem. Biophys. 82(1): 70-77.

El-Morsy, E.M. \& Kamel, R. 2015. Protective effect of artichoke leaf extract against paracetamol-induced hepatotoxicity in rats. Pharm. Biol. 53(2): 167-173.

Ferreira, J.F.S., Luthria, D.L., Sasaki, T. \& Heyerick, A. 2010. Flavonoids from Artemisia annua L. as antioxidants and their potential synergism with artemisinin against malaria and cancer. Molecules 15(5): 3135-3170.

Friedewald, W.T., Levy, R.I. \& Fredrickson, D.S. 1972. Estimation of the concentration of low-density lipoprotein cholesterol in plasma without use of the preparative ultracentrifuge. Clin. Chem. 18(6): 499-502.

Gupta, A., Sheth, N.R., Pandey, S., Yadav, J.S. \& Joshi, S.V. 2015. Screening of flavonoids rich fractions of three Indian medicinal plants used for the management of liver diseases. Rev. Brasil Farmacog. 25(5): 485-490.

Güvenç, M., Cellat, M., Gökçek, I., Özkan, H., Arkalı, G., Yakan, A., Özsoy, S.Y. \& Aksakal, M. 2020. Nobiletin attenuates acetaminophen-induced hepatorenal toxicity in rats. J. Biochem. Mol. Toxicol. 34(2): e22427.

Halliwell, B. \& Gutteridge, J.M. 1984. Oxygen toxicity, oxygen radicals, transition metals and disease. Biochem. $J$. 219(1): 1-14.

Hasanein, P. \& Sharifi, M. 2017. Effects of rosmarinic acid on acetaminophen-induced hepatotoxicity in male Wistar rats. Pharm. Biol. 55(1): 1809-1816.

Kandemir, F.M., Kucukler, S., Eldutar, E., Caglayan, C. \& Gülçin, I. 2017. Chrysin protects rat kidney from paracetamolinduced oxidative stress, inflammation, apoptosis, and autophagy: A multi-biomarker approach. Sci. Pharm. 85(1): 4.

Kanno, S., Tomizawa, A. \& Yomogida, S. 2016. Detecting mRNA predictors of acetaminophen-induced hepatotoxicity in mouse blood using quantitative real-time PCR. Biol. Pharm. Bull. 39(3): 440-445.

Kanungo, S.K., Panda, D.S., Swain, S.R., Barik, B.B. \& Tripathi, D.K. 2007. Comparative evaluation of hypolipidemic activity of some marketed herbal formulations in triton induced hyperlipidemic rats. Pharmacologyonline 3: 211-221.

Kosanic, M. \& Rankovic, B. 2011. Lichens as possible sources of antioxidants. Pak. J. Pharm. Sci. 24(2): 165-170. 
Krithika, R. \& Verma, R.J. 2019. Solanum nigrum confers protection against $\mathrm{CCl} 4$-induced experimental hepatotoxicity by increasing hepatic protein synthesis and regulation of energy metabolism. Clin. Phytosci. 5(1): $1-8$.

Lorke, D. 1983. A new approach to practical acute toxicity testing. Arch. Toxicol. 54(4): 275-287.

Mahesh, B.U., Shrivastava, S., Pragada, R.R., Naidu, V.G.M. \& Sistla, R. 2014. Antioxidant and hepatoprotective effects of Boswellia ovalifoliolata bark extracts. Chin. J. Nat. Med. 12(9): 663-671.

Maheswari, C., Maryammal, R. \& Venkatanarayanan, R. 2008. Hepatoprotective activity of Orthosiphon stamineus on liver damage caused by paracetamol in rats. Jordan J. Biol. Sci. 1(3): 105-108.

Mandal, A., Patra, A., Mandal, S., Roy, S., Mahapatra, S.D., Mahapatra, T.D., Paul, T., Das, K., Mondal, K.C. \& Nandi, D.K. 2015. Therapeutic potential of different commercially available synbiotic on acetaminophen-induced uremic rats. Clin. Exp. Nephrol. 19(2): 168-177.

Marotta, F., Yadav, H., Gumaste, U., Helmy, A., Jain, S. \& Minelli, E. 2009. Protective effect of a phytocompound on oxidative stress and DNA fragmentation against paracetamol induced liver damage. Ann. Hepatol. 8(1): 50-56.

Martin, P. \& Friedman, L.S. 1992. Assessment of liver function and diagnostic studies. In Hand Book of Liver Disease, edited by Friedman, L.S. \& Keeffe, E.B. Philadelphia: Churchill Livingstone. pp. 1-14.

Mayne, P.D. 1994. The kidneys and renal calculi. In Clinical Chemistry in Diagnosis and Treatment, edited by Mayne, P.D. London, UK: Edward Arnold Publications. pp. 2-24.

McCord, J.M. \& Fridovich, I. 1969. Superoxide dismutase. An enzymatic function for erythrocuperin (hemocuprein). $J$. Biol. Chem. 244(2): 6045-6055.

Mitra, S.K., Seshadri, S.J., Venkataranganna, M.V., Gopumadhavan, S., Udupa, U.V. \& Sarma, D.N. 2000. Effect of HD-03 - a herbal formulation in galactosamineinduced hepatopathy in rats. Indian J. Physiol. Pharmacol. 44(1): 82-86.

National Research Council. 1985. Guide for the Care and the Use of Laboratory Animals. 20. Bethesda, MD.

Okokon, J.E., Simeon, J.O. \& Umoh, E.E. 2017. Hepatoprotective activity of the extract of Homalium letestui stem against paracetamol-induced liver injury. Avicenna $J$. Phytomed. 7(1): 27-36.

Olatunji, L.A., Adebayo, J.O., Oguntoye, O.B., Olatunde, N.O., Olatunji, V.A. \& Soladoye, A.O. 2005. Effects of aqueous extracts of petals of red and green hibiscus sabdariffa on plasma lipid and hematological variables in rats. Pharm. Biol. 43(5): 471-474.

Orlić, L., Mikolasevic, I., Bagic, Z., Racki, S., Stimac, D. \& Milic, S. 2014. Chronic kidney disease and nonalcoholic fatty liver disease-is there a link? Gastroenterol. Res. Pract. 2014: 847539 .
Oteng-Amoako, A.A. \& Obeng, E.A. 2012. Copaifera salikounda Heckel. http://www.prota4u.org/search.asp. Accessed on 4th September, 2017.

Patel, D.K., Patel, K.A., Patel, U.K., Thounaojam, M.C., Jadeja, R.N., Ansarullah, Padate, G.S., Salunke, S.P., Devkar, R.V. \& Ramachandran, A.V. 2009. Assessment of lipid lowering effect of Sida rhomboidea Roxb methanolic extract in experimentally induced hyperlipidemia. J. Young Pharm. 1(3): 233-238.

Pedraza-Chaverrí, J., Barrera, D., Hernández-Pando, R., MedinaCampos, O.N., Cruz, C., Murguía, F., Juárez-Nicolás, C., Correa-Rotter, R., Torres, N. \& Tovar, A.R. 2004. Soy protein diet ameliorates renal nitrotyrosine formation and chronic nephropathy induced by puromycin aminonucleoside. Life Sci. 74(8): 987-999.

Pigeolet, E., Corbisier, P., Houbion, A., Lambert, D., Michiels, C, Raes, M., Zachary, M.D. \& Remacle, J. 1990. Glutathione peroxidase, superoxide dismutase, and catalase inactivation by peroxides and oxygen derived free radicals. Mech. Ageing Dev. 51(3): 283-297.

Pithayanukul, P., Nithitanakool, S. \& Bavovada, R. 2009. Hepatoprotective potential of extracts from seeds of Areca catechu and nutgalls of Quercus infectoria. Molecules, 14(12): 4987-5000.

Plaa, G.L. \& Hewitt, W.R. 1989. Detection and evaluation of chemically induced liver injury. In Principles and Methods of Toxicology, edited by Wallace Hayes, A. New York: Raven Press. pp. 399-628.

Prakash, J., Gupta, S.K., Kochupillai, V., Singh, N., Gupta, Y.K. \& Joshi, S. 2001. Chemopreventive activity of Withania somnifera in experimentally induced fibrosarcoma tumours in Swiss albino mice. Phytother. Res. 15(3): 240244.

Rotruck, J.T., Pope, A.L., Ganther, H.E., Swanson, A.B., Hafeman, D.G. \& Hoekstra, W.G. 1973. Selenium: Biochemical role as a component of glutathione peroxidase. Science 179(4073): 588-590.

Saleem, T.S.M., Christina, A.J.M., Chidambaranathan, N., Ravi, V. \& Gauthaman, K. 2008. Hepatoprotective activity of Annona squamosa (Linn) on experimental animal model. Int. J. Appl. Res. Nat. Prod. 1(3): 1-7.

Sallie, R., Tredger, J.M. \& William, R. 1991. Drugs and the liver. Part I: testing liver function. Biopharm. Drug Dispos. 12(4): 251-259.

Samuel, A.J.S.J., Mohan, S., Chellappan, D.K., Kalusalingam, A. \& Ariamuthu, S. 2012. Hibiscus vitifolius (Linn.) root extracts shows potent protective action against anti-tubercular drug induced hepatotoxicity. J. Ethnopharmacol. 141(1): 396-402.

Sandhar, H.K., Kumar, B., Prasher, S., Tiwari, P., Salhan, M. \& Sharma, P. 2011. A review of phytochemistry and pharmacology of flavonoids. Int. Pharm. Sci. 1(1): 25-41.

Scott, M.D., Lubin, B.H., Zuo, L. \& Kuypers, F.A. 1991. Erythrocyte defense against hydrogen peroxide: Preeminent importance of catalase. J. Lab. Clin. Med. 118(1): 7-16. 
Sinha, K.A. 1972. Colorimetric assay of catalase. Anal. Biochem. 47(2): 389-394.

Srinivasan, V., Panneerselvam, R., Gunasekaran, S. \& Palani, S. 2014. Ethanolic extract of Melia azadirachta against acetaminophen induced nephrotoxicity. Int. J. PharmTech Res. 6(1): 70-79.

Tapas, A.R., Sakarkar, D.M. \& Kakde, R.B. 2008. Flavonoids as nutraceuticals: A review. Trop. J. Pharm. Res. 7(3): 10891099.

Ulrich, I.H. 1987. Evaluation of a high-fiber diet in hyperlipidemia: A review. J. Am. Coll. Nutr. 6(1): 19-25.

Vidal-Quintanar, R.L., Hernandez, L., Conde, K., VergaraJimenez, M. \& Fernandez, M.L. 1997. Lime-treated corn husks lower plasma LDL-cholesterol in guinea pigs by altering hepatic cholesterol metabolism. J. Nutr. Biochem. 8(8): 479-486

Yang, D., Lin, S., Yang, D., Wei, L. \& Shang, W. 2012. Effects of short- and long-term hypercholesterolemia on contrastinduced acute kidney injury. Am. J. Nephrol. 35(1): 80-89.

Yao, H.T., Luo, M.N. \& Li, C.C. 2015. Chitosan oligosaccharides reduce acetaminophen-induced hepatotoxicity by suppressing CYP-mediated bioactivation. J. Funct. Foods 12: 262-270.

Yokozawa, T. \& Dong, E. 2001. Role of ginsenoside-Rd in cisplatin-induced renal injury: Special reference to DNA fragmentation. Nephron 89(4): 433-438.

Yousef, M.I., Omar, S.A.M., El-Guendi, M.I. \& Abdelmegid, L.A. 2010. Potential protective effects of quercetin and curcumin on paracetamol-induced histological changes, oxidative stress, impaired liver and kidney functions and haematotoxicity in rat. Food Chem. Toxicol. 48(11): 32463261.
Zhao, B. \& Hu, M. 2013. Gallic acid reduces cell viability, proliferation, invasion and angiogenesis in human cervical cancer cells. Oncol. Lett. 6(6): 1749-1755.

Chinyere Aloke*, Nwogo Ajuka Obasi, Patience Nkemjika Ogbu, Godswill Odumero Ufebe, Egwu Chinedu Ogbonnia \& Anthony Chinwendu Onyekwere

Department of Medical Biochemistry

Faculty of Basic Medical Sciences

Alex Ekwueme Federal University

Ndufu-Alike, Ebonyi State

Nigeria

Chinedum Uche Emelike

Department of Physiology

Faculty of Basic Medical Sciences

Alex Ekwueme Federal University

Ndufu-Alike, Ebonyi State

Nigeria

Onyebuchi Federick Orinya

Department of Medical Biochemistry

Faculty of Basic Medical Sciences

Ebonyi State University

Abakaliki Ebonyi State

Nigeria

*Corresponding author; email: alokec2002@yahoo.com

Received: 8 April 2020

Accepted: 18 September 2020 